ACTA AGROBOTANICA

Vol. 59, z. 12006

s. 2939

\title{
Diversity of the floral nectaries surface of four Crataegus L. species
}

\section{MIROSŁAWA CHWIL, AGATA KONARSKA, ELŻBIETA WERYSZKO-CHMIELEWSKA}

\author{
Department of Botany, Agricultural University of Lublin, Akademicka 15 Street, \\ 20950 Lublin, Poland \\ e mail: miroslawa.chwil@ar.lublin.pl
}

(Received: 24.11.2005)

\section{S u m m ary}

The performed studies focused on the surface structure of floral nectaries of four species from the following genus: C. coccinea $\mathrm{L}, C$. crus-galli $\mathrm{L}, C$. curvisepala Lindm and $C$. prunifolia (Poiret) Pers. The observations of the epidermis area were made in a scanning electron microscope (SEM). A nectary appears to be shaped like a slightly curved disk situated between the pistil style and the basal part of the stamens filaments. The nectary area of the studied species differed substantially as regards the cuticle sculpture and stomata number. The nectary secretion in Crataegus flowers proceeds through the stomata located below a level of the other epidermis cells, in the deep indents of the secretory tissue. The highest stomata number in $1 \mathrm{~mm}^{2}$ nectary epidermis was recorded in C. crus-galli, C. coccinea, C. prunifolia and finally, C. curvisepala. Analyzing the nectary cuticular structure in respect of its increasing complexity (absence or presence of stripes), the investigated taxons can be ordered as following: Crataegus curvisepala, C. coccinea, C. crus-galli and C. prunifolia.

Key words: floral nectaries, epidermis, nectary stomata, cuticle, SEM, Crataegus L., Rosaceae

\section{INTRODUCTION}

Species from the Crataegus L. genus (f. Rosaceae, subf. Pomoideae) are found most frequently in North America. The following species, among others, are often cultivated in Poland: C. coccinea L., C. curvisepala Lindm., C. crus-galli L. and C. prunifolia (Poiret) Pers (S e n e t a and D o l a t o w s k i , 1997). Many of them are used in urban plantings on account of their ornamental flowers, fruit and leaves, as well as their medicinal properties (Rutk ow ski, 1998; Asgary et al., 1998; Wang, 1998). Trees 
from the Crataegus genus are characterised by abundant nectar secretion and are included among valuable melliferous plants (Li piński, 1976; S e neta and Dolatow s k i, 1997). Among honey types, hawthorn honey is also distinguished (R o berts, 1994). Previously conducted studies show that within the Crataegus genus there are large differences in the amount of nectar secreted by flowers and the concentration of sugar in the nectar (Jabłoński and Kołtowski, 1996; Weryszko$\mathrm{Ch} \mathrm{mi} \mathrm{e} \mathrm{le} \mathrm{w} \mathrm{s} \mathrm{k} \mathrm{a} \mathrm{et} \mathrm{al.,} \mathrm{1996).} \mathrm{The} \mathrm{sugar} \mathrm{yield} \mathrm{of} \mathrm{several} \mathrm{previously} \mathrm{studied} \mathrm{hawthorn}$ species ranged between 0.33 and $4.22 \mathrm{mg}$ of sugars from 10 flowers. The highest weight of sugars was found in C. crus-galli, while the lowest in C. coccinea (We r y s z k o$\mathrm{C} \mathrm{h} \mathrm{mi} \mathrm{e} \mathrm{le} \mathrm{w} \mathrm{s} \mathrm{k} \mathrm{a} \mathrm{et} \mathrm{al.,} \mathrm{1996,} \mathrm{2003b).} \mathrm{Due} \mathrm{to} \mathrm{the} \mathrm{content} \mathrm{of} \mathrm{particular} \mathrm{types} \mathrm{of} \mathrm{sugars,}$ the nectar of hawthorns was included in the "Pyrus - type", in which little sucrose occurs and the amount of glucose significantly exceeds the content of fructose (M a u ri z i o and $\mathrm{Gr}$ a f 1, 1969). Hitherto, it has been observed that cells of the nectary epidermis demonstrate large differences in the surface, also between the genera within the Pomoideae subfamily (Weryszko-Chmielewska and Konarska, 1995, 1996; To th et al., 2000; We ry s z k o- C h m ie le w s k a et al., 2003a, 2004). The structure of the epidermis of the nectary gland is one of the factors affecting the amount of nectar secreted. The structural features of nectaries may also be of taxonomic value.

The aim of this study was to compare the surface structure of the secretory tissue of nectaries in four species from the Crataegus genus, with special attention to the cuticular ornamentation and the position of secretory stomata. The number of stomata found in $\mathrm{mm}^{2}$ of the nectary epidermis was also determined.

\section{MATERIALS AND METHOD}

The studies conducted related to the structure of floral nectaries of Crataegus coccinea L., C. crus-galli L., C. curvisepala Lindm. and C. prunifolia (Poiret) Pers. Trees from which flowers were sampled grew in the Botanical Garden of the Maria Curie-Skłodowska University in Lublin.

For the scanning electron microscopy (SEM) examination of the surface of the nectary epidermis, fragments of flowers were fixed in $4 \%$ glutaraldehyde 4 and $(0.1 \mathrm{M})$ phosphate buffer with $\mathrm{pH} 7.0$ for 4 hours at room temperature. After dehydrating the specimens in ethanol series and acetone, they were dried at critical point with liquid $\mathrm{CO}_{2}$. Then the plant material was coated with gold by using the CS 100 Sputter Coater 100 . Observations of the surface of the nectary epidermis in the aforementioned taxa were carried out by using the BS-300 Tesla microscope.

In the longitudinal sections, the thickness of the secretory tissue was compared based on semi-permanent slides from fresh plant material which were obtained by using the Vibratome 2000 (Technical Product International INC, USA). The $60 \mu \mathrm{m}$ thick sections were embedded in glycerol-gelatine.

In order to prepare semi-thin sections, the plant material was postfixed with $1 \%$ osmium tetroxide, then dehydrated and embedded in Spurr's epoxy resin. Sections of 0.75 $\mu \mathrm{m}$ thickness were cut by using the Reichert Ultracut $\mathrm{S}$ ultramicrotome, then stained with $1 \%$ methylene blue with $1 \%$ azur II. The sections were mounted in synthetic resin Eukitt. 


\section{RESULTS}

The flowering of the aforementioned species occurs in May and June. The length of this period in the climatic conditions of Lublin was about 14 days. Flowers of the taxa studied were characterised by a white corolla and bright red anthers, as well as a diverse structure of the pistil. C. coccinea, C. prunifolia and C. crus-galli flowers develop a distyloulos pistil, whereas in C. curvisepala a monostylous pistil occurs (Figs 1-4).
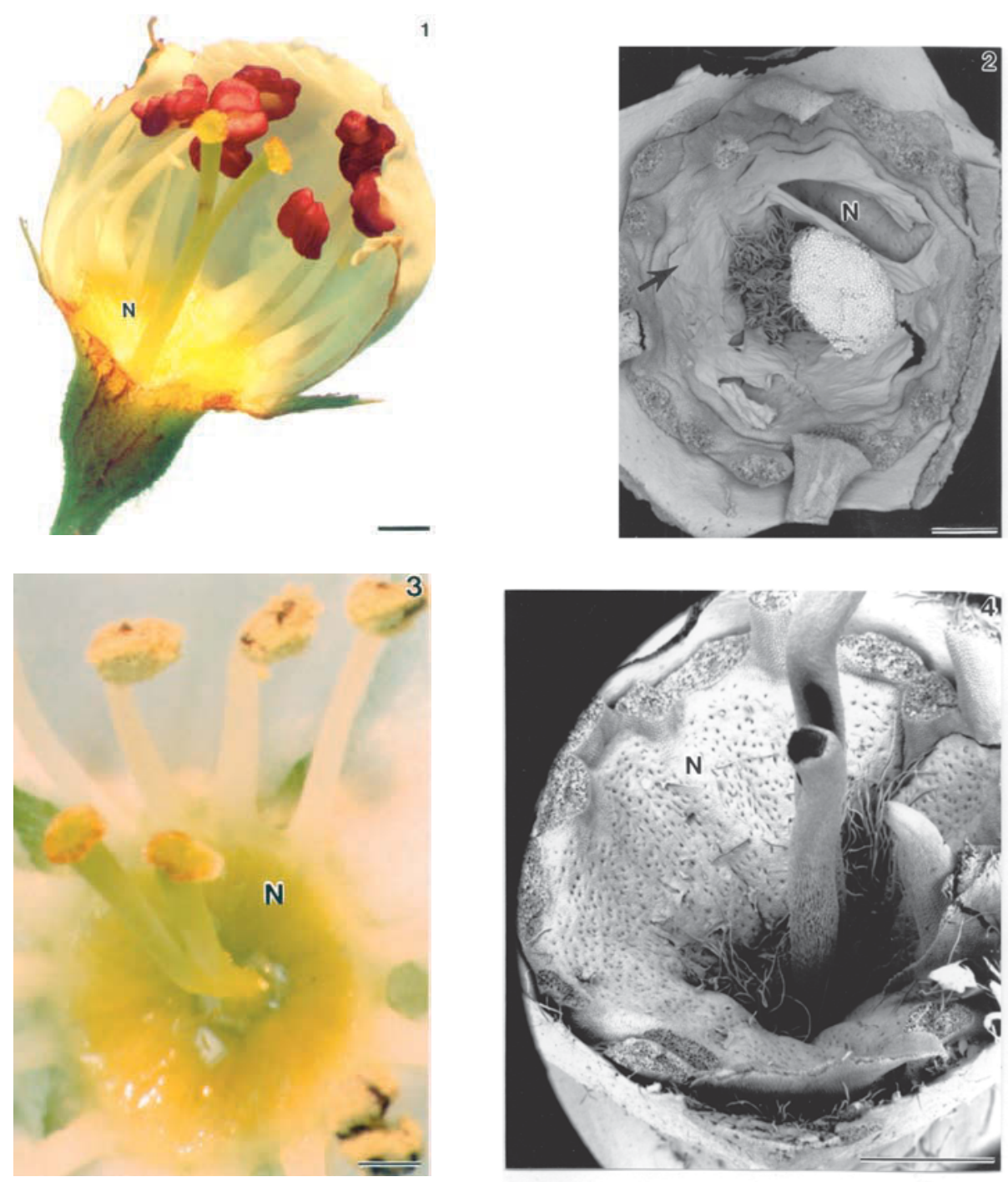

Figs 14 . Fragments of the flowers of three Crataegus species: 1, 4 C. prunifolia, 2 C. curvisepala, 3 C. coccinea; visible nectary surface $(\mathrm{N})$ and dry nectar (arrow). Bars 2 mm (figs 1, 2, 3, 4). 
Around the style of the pistil in the four species studied, numerous, strongly elongated unicellular hairs were observed in the epidermis of the nectary tissue (Figs 2, 4-6).

Nectar in the analysed flowers of the Crataegus representatives is easily accessible for insects, since stamens and elements of the perianth, when opening during flowering, uncover the nectary gland, situated on the adaxial surface of the concave flower receptacle. The nectary was yellow coloured, and it covered the surface between the style of the pistil and the basal part of filaments (Figs 1-6). The secretory tissue

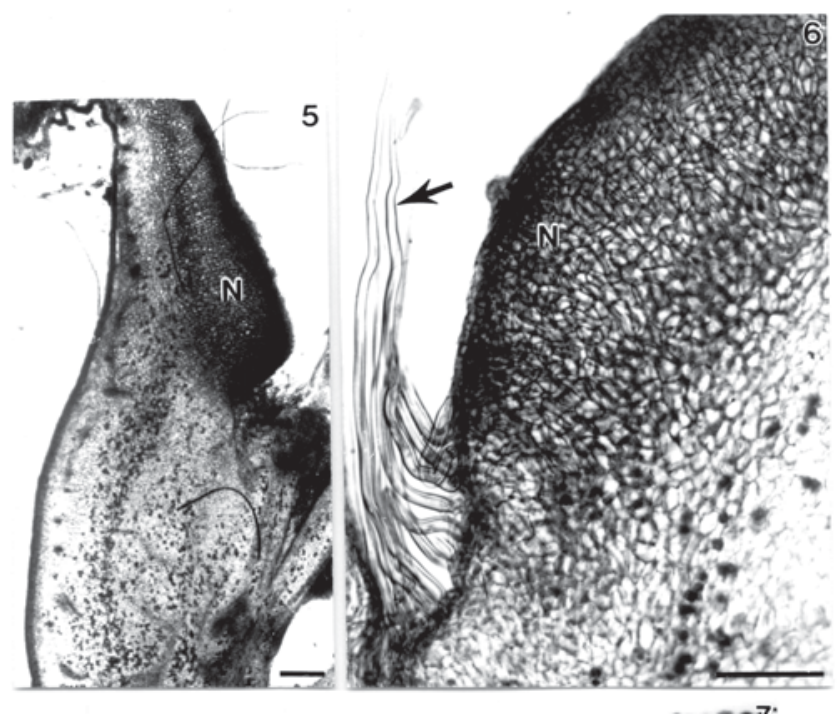

Figs 5 6. Longitudinal sections of lower part of Crataegus coccinea flower with nectary (N), visible numerous trichomes (arrow) at the style base. Bars $150 \mu \mathrm{m}$ (fig. 6), $200 \mu \mathrm{m}$ (fig. 5).

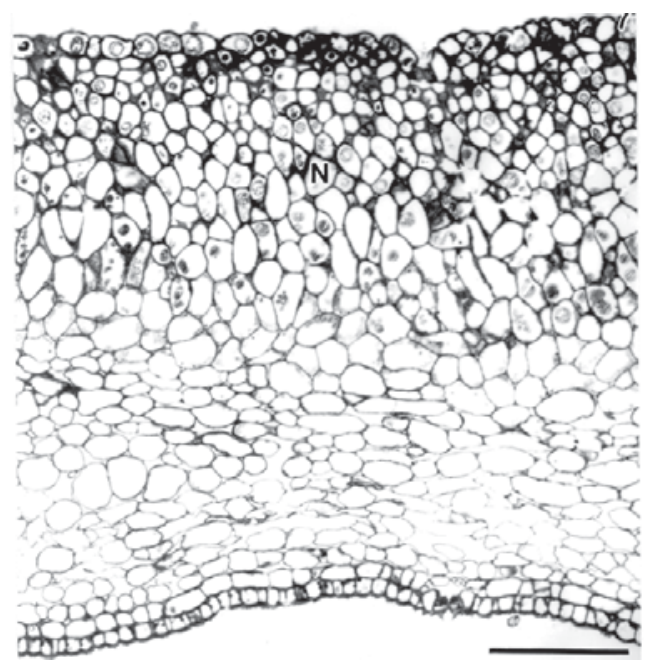

Fig. 7. Longitudinal section of nectary tissue (N) C. crus galli. Bar $200 \mu \mathrm{m}$. 

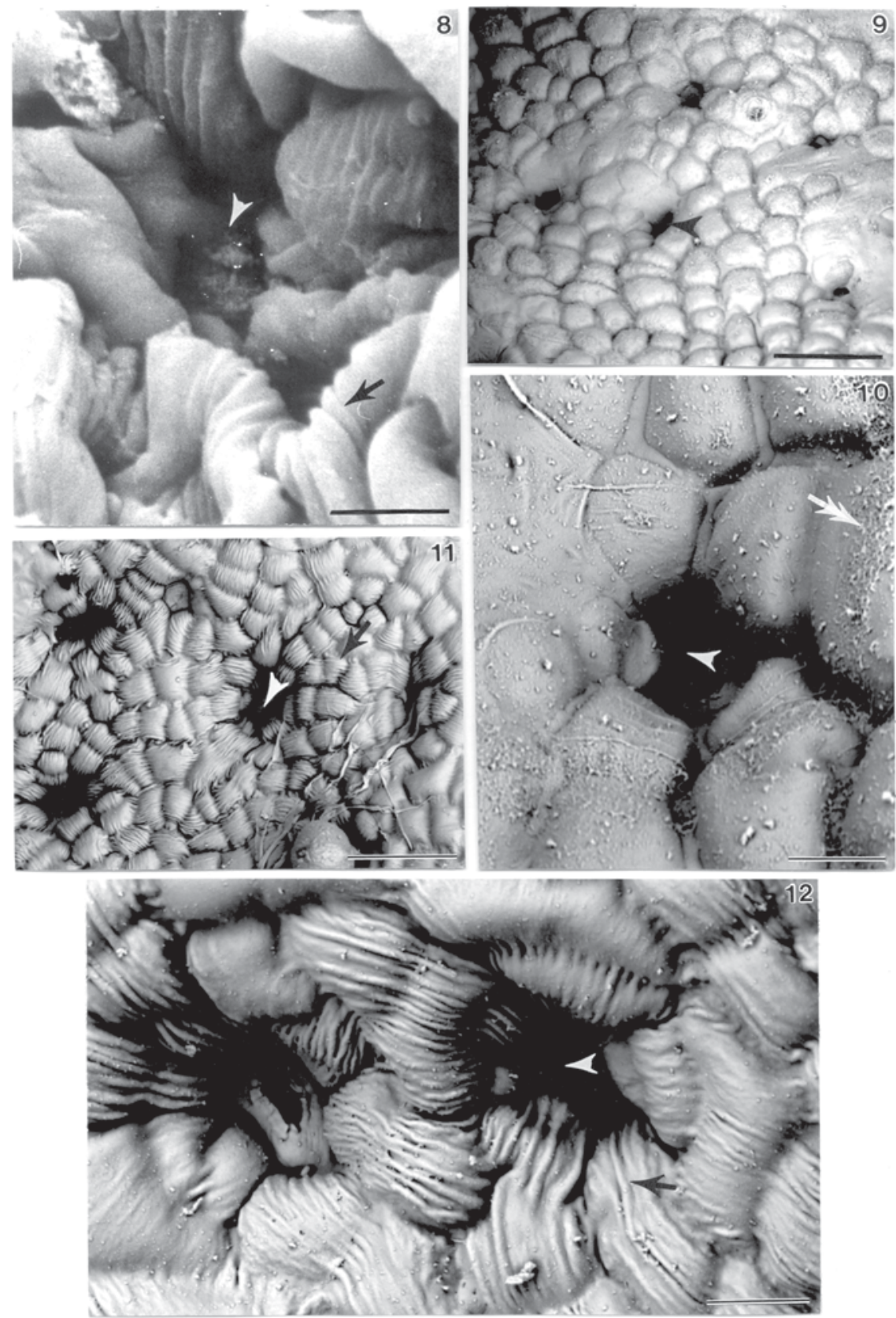

Figs 8 12. Fragments of the nectary epidermis surface of three Crataegus species: 8 C. crus galli; 9,10 C. curvisepala; 11, 12 C. prunifolia; visible cells with smooth and striated (arrow) cuticle, stomata (arrow head) in depressions of secretion tissues and wax coating (double arrow). Bars $5 \mu \mathrm{m}$ (fig. 8), $10 \mu \mathrm{m}$ (figs 10,12); $50 \mu \mathrm{m}$ (figs 9, 11). 


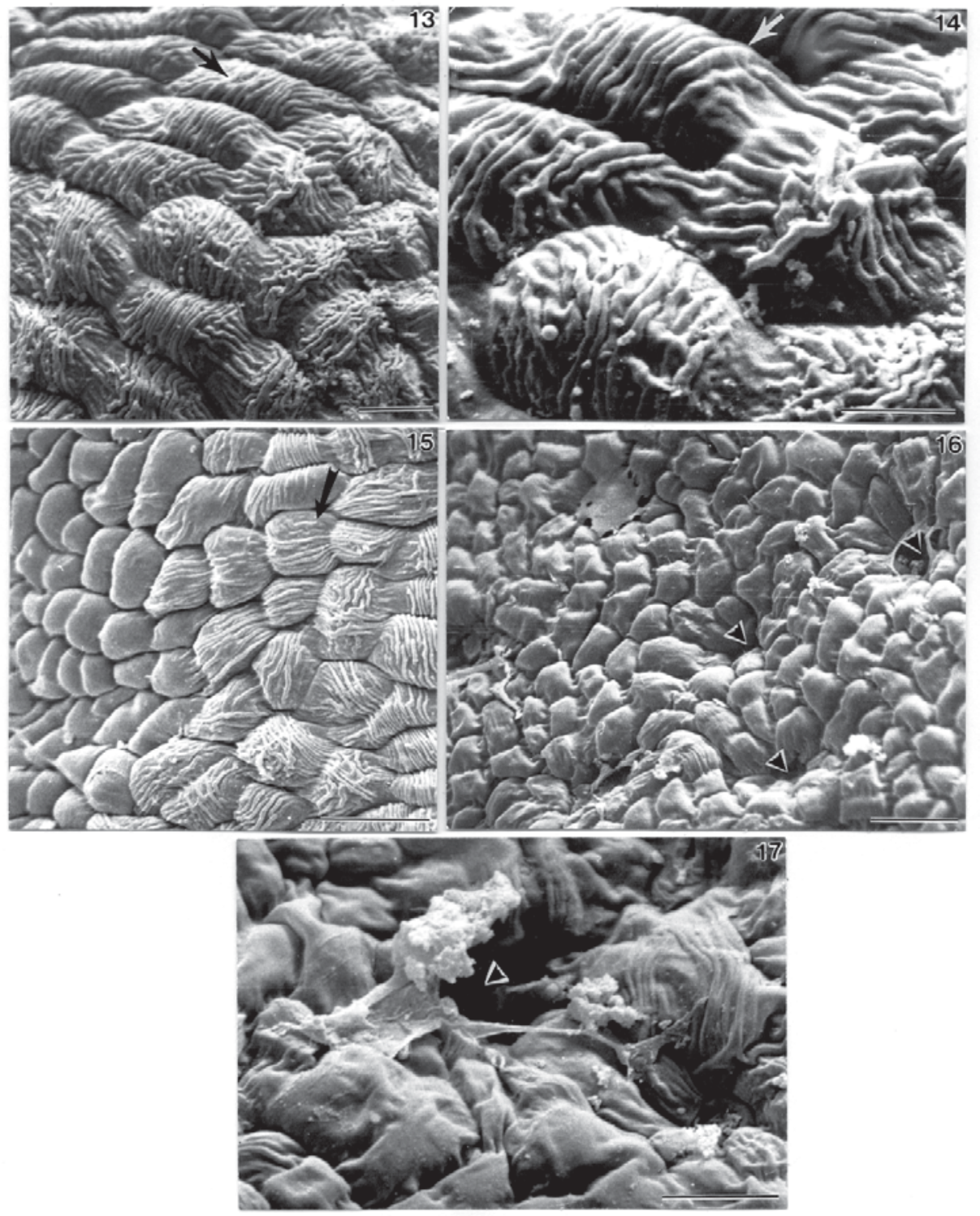

Figs 13 17. Fragments of nectary epidermis surface of Crataegus coccinea, 1315 the cells of epidermis from upper part of nectary with striped cuticle (arrows), 1617 the cells from the lower part of nectary with smooth and corrugated cuticle at stomata (arrow head) laid in depressions. Bars: $5 \mu \mathrm{m}$ (figs 14, 17); $20 \mu \mathrm{m}$ (figs 13, 15, 16). 
was characterised by a several-layers of cells, and it made up half of the thickness of the flower receptacle in this region (Figs 5-7).

Observed from above, the contour of the epidermis cells covering the nectary tissue in flowers of the taxa studied had a quadrangular shape (Figs 8-12, 16, 17). Nectar is secreted through stomata located below the level of the other cells of the nectary epidermis (Figs 8-12, 16, 17). As a result of a large depression, it was difficult to determine the aperture of the stomata, it was only found in $C$. prunifolia that they were open (Fig. 12). The modified stomata occurring in the epidermis of the nectaries of the observed species from the Crataegus genus were classified as anomocytic. They are characterised by the occurrence of a variable number of epidermis cells which surround the guard cells in a ring, and they do not differ from other cells of the epidermis (Figs 9-12, 16). The studied species of hawthorn developed a large number (175-308) of stomata in $\mathrm{mm}^{2}$ of the nectary epidermis. The largest number of stomata was recorded in the epidermis of $C$. crus-galli, a much smaller number in C. coccinea, C. prunifolia, and C. curvisepala (tab. 1). The stomata were evenly distributed over the whole surface of the nectary (Figs 9, 11, 16).

Table 1

Number of stomata and kind of cuticle ornamentation of four species from Crataegus genus.

\begin{tabular}{|l|c|c|}
\hline \multicolumn{1}{|c|}{ Species } & Number of stomata in $\mathrm{mm}^{2}$ epidermis & Cuticle \\
\hline C. coccinea & 216 & faintly striped \\
\hline C. crus galli & 308 & faintly striped \\
\hline C. curvisepala & 175 & smooth \\
\hline C. prunifolia & 185 & greatly striped \\
\hline
\end{tabular}

The observations in scanning electron microscopy show that the outer wall of the nectary epidermis was covered by a layer of the cuticle differing in the ornamentation in particular taxa. The cuticle on the surface of the epidermis cells of the C. curvisepala nectary was smooth with wax coating which formed in some places an irregular, reticulate structure (Figs 9, 10). Some cells of the epidermis in C. coccinea and $C$. crus-galli showed clear striation of the cuticle, and other cells had a smooth surface (Figs 8, 13 17). On the surface of the C. crus-galli nectary, cuticular striae were observed in some places, undulate and interleaved, forming an ornamentation partly concealing the contours of the epidermis cells (Figs 8). But cells of the epidermis covering the $C$. prunifolia nectary tissue had clear cuticular sculpture in the form of longitudinal, slightly undulate striae running parallel within particular cells and radially around the stomata (Figs 11,12 ). When analysing the cuticular sculpture of the nectary epidermis in terms of the increasing degree of complexity of structure, the taxa studied can be ranked as follows: Crataegus curvisepala, C. coccinea, C. crusgalli and C. prunifolia. 


\section{DISCUSSION}

The nectaries in flowers of the taxa studied from the Crataegus genus form on the surface of the flower receptacle, a glandular layer which, according to S mets (1986), developed from the reduced stamen whorl in the Rosidae subclass. Fre y Wy s s ling (1955) found that the disc nectary belongs to highly specialised structures occurring within the abovementioned plant subclass. In terms of the form in the Pomoideae, the following types of nectaries were distinguished: automorphic (Crataegus, Pyrus, Chaenomeles), epimorphic (Cydonia) and transitoric (Malus) (W e r y s z ko-Chmielewska and Konarska, 1995; 1996).

Literature data show that nectaries of plants belonging to the Rosidae can be divided in terms of the presence or absence of modified stomata (Smets, 1988). Another division, relating to the tissue origin of nectaries, defines them as mesophilic (Vog e 1, 1977; S c h mid, 1988).

In flowers of the studied taxa from the Crataegus genus the presence of the secretory tissue was found, secreting nectar through anomocytic stomata. The state of opening of the stomata in C. curvisepala, C. crus-galli and C. coccinea was difficult to determine due to their deep location. In the longitudinal sections of flowers, it was observed that the stomata in $C$. crus-galli and $C$. coccinea reach the second level of the glandular cells, which were characterised by a thick wall, numerous plastids with starch grains and a high degree of vacuolisation (We ry s zk o-Ch mie lew ska et al., 2003b).

Open stomata in the epidermis of the nectaries analysed in the present study of hawthorns were only visible in Crataegus prunifolia. However, earlier studies of We r y s z k o-Ch mi e le w s k a et al. (2003b) showed the presence of closed stomata in the secretory tissue of Crataegus crus-galli, in spite of the fact that observations were carried out during the secretion period, while in Malus (To th et al, 2000) the stomata were characterised by different apertures, what indicates their ability to open and close. These observations suggest the active functioning of stomata in the epidermis of nectaries of the abovementioned taxa, what is related to the rhythmic secretion of nectar (Toth et al., 2000; Weryszko-Ch mielewska et al, 2003b).

Among the analysed species from the Crataegus genus, the largest number of stomata on the surface area of $1 \mathrm{~mm}^{2}$ of the nectary epidermis was observed in C. crusgalli, and the lowest in C. curvisepala. In many plant species, a positive correlation between the number of stomata in the nectary epidermis and the abundance of nectar secretion was found (Teuber et al, 1980; Murrell et al. 1982; Davis and Gunning, 1991; Weryszko-Chmielewska et al., 1997). One can expect that a similar dependence applies to nectaries of all the Crataegus species studied, since it was previously demonstrated for $C$. crus-galli and $C$. coccinea (We r y s z k o Chmielewska et al., 2003b).

Crataegus prunifolia is a species developed as a result of crossing of C. crus-galli and C. macracantha (Rutkowski, 1998). In spite of the very close affinity 
of $C$. crus-galli and C. prunifolia, significant differences were demonstrated in the structure of the surface of the nectary epidermis in these species. The cuticle was characterised by a different ornamentation, from partially striate in C. crus-galli to strongly striate over the whole surface in C. prunifolia. In the four Crataegus species studied, a total of 3 types of the nectary surface, related to the cuticular sculpture, were distinguished: smooth, striate in some places and striate over the whole surface. The striate sculpture of the cuticle of the nectary probably performs different functions, among others, protects nectar against drying and facilitates the distribution of the secretion over the surface of the nectary. According to H e j n o w i c z (2002), the rich cuticular sculpture more effectively "repels" from the epidermis rainwater drops which, when falling, do not flatten, and rolling over the surface, they enable it to self-clear. In its composition, the cuticle contains special carbohydrates, and on its surface waxes deflecting excessive UV radiation. It is particularly important, especially for the glandular tissue unprotected by stamens and the perianth. This layer also helps to limit the penetration of different chemical substances affecting plants.

At the same time, the cuticle, which is a complex compound made up of strongly polymerised fatty acids resistant to the action of water, is characterised by chemical stability (E s a u , 1973; H e j n o w i c z , 2002), thanks to which it does not decompose. Esau (1973) states that no microorganism decomposes the cuticle, since it does not have any enzymes which degrade the cutin. As a result of this, the cuticle of the nectary epidermis is an important mechanical barrier against unfavourable conditions of the environment, among others: infection, damage by the wind and insects.

Significant differences, observed in this study, in the micromorphology of the nectaries of closely related species within the Crataegus genus may result from adaptations to different habitat conditions in which they occur in natural locations. According to He y w o o d (1974), the varied cuticular ornamentation may be used as a taxonomic value.

\section{CONCLUSIONS}

1. In flowers of the studied species from the Crataegus genus, nectar is secreted through anomocytic stomata located in deep depressions of the secretory tissue.

2. The largest amount of stomata for one unit of surface area was found in the epidermis of the C. crus-galli nectaries, then in C. coccinea, C. prunifolia and C. curvisepala.

3. The epidermis covering the floral nectaries in the studied species from the Crataegus genus formed three types of cuticular ornamentation: smooth, partially striate and strongly striate.

4. In terms of the increasing degree of complexity of cuticular sculpture, the Crataegus nectaries can be ranked as follows: Crataegus curvisepala, C. coccinea, C. crus-galli and C. prunifolia. 


\section{REFERENCES}

Asgary S., Sarrafzadegas N., Ghas semi N., Ghannadi A., Sajadi S. E., $\mathrm{S}$ a j j a d i F., N a d e r i G., 1998. Antihyperlipidemic effects of Crataegus curvisepala Lind. Int. Cardiol. 7 (2): 7375.

D a v is A. R., Gun n ing B. E. S., 1991. The modified stomata of the floral nectary of Vicia faba. 2. Stomata number and distribution as selection criteria for breeding for high nectar sugar production. Acta Hort. 288: 329334.

E s a u K., 1973. Anatomia roślin. PWRiL, Warszawa.

Frey Wyssling A., 1955. The phloem supply to the nectaries. Acta Bot. Neerl. 4 (3): 358369.

He jn ow ic z Z., 2002. Anatomia i histogeneza roślin naczyniowych: organy wegetatywne. Państwowe Wydawnictwo Naukowe, Warszawa.

He y w o o d V. H., 1974 Taksonomia roślin. Państwowe Wydawnictwo Naukowe, Warszawa.

J a b ł o ń s k i B., K o ł t o w s k i Z., 1996. Nektarowanie i wydajność miodowa roślin w warun kach. Polski. Część IX. Pszczel. Zesz. Nauk. 40: 5965.

L i p i ń s k i M., 1976. Pożytki pszczele: zapylanie i miododajność roślin. Państwowe Wydawnic two Rolnicze i Leśne, Warszawa.

Maurizi o A., Graf1 I., 1969. Das Trachtpflanzenbuch. Ehrenwirth Verlag, München.

Murrel1 D. C., Shuel R. W., Tomes D. T., 1982. Nectar production and floral characteri stics in birdsfoot trefoil (Lotus corniculatus L.) Can. J. Plant. Sci. 62: 101105.

R o be r t s P., 1994. What are the important nectar sources for honey bees? In. Matheson A. [ed.] Forage for bees in an agricultural landscape: 21 33. International Bee Research Associa tion, Cardiff, UK.

R u t k o w s k i L., 1998. Klucz do oznaczania roślin naczyniowych Polski niżowej. Wydawnic two Naukowe PWN, Warszawa.

S e n e t a W., D o l a t o w s k i J., 1997. Dendrologia. Wydawnictwo Naukowe PWN, Warszawa.

S m e t s E., 1986. Localization and systematic importance of the floral nectarines in the Magnolia tae (Dicotyledons). Bull. Jard. Bot. Nat. Belg. 56: 5176.

S m e t s E., 1988. La presence des "nectaria persistentia" chez les Magnoliophytina (Angiosper mes). Candollea, 43: 709716.

S c h m i d R., 1988. Reproductive versus extra reproductive nectaries historical perspective and terminolocal recommendation. Bot. Review, 54: 179232.

Teuber L. R., Albersten M. C., B arnes D. K., Hei chel G. H., 1980. Structure of floral nectarines of alfalfa (Medicago sativa L.) in relation to nectar production. Am. J. Bot. 67: 433439.

Toth E. N., B uban T., Hevesi M., Orosz Kovacs Z., S zabo L. G., 2000. Morpho logical characteristics of the nectary and composition of nectar of selected apple cultivars. Acta Hortic. 538 (1): 301308.

Vo ge l S., 1977. Nectarien und ihre ökologische Bedeutung. Apidologie, 8: 321335.

Wang J. G., 1998. Wulenghong, a new hawthorn variety. Chin. Fruits. 2: 55.

Weryszko Chmielewska E., Chwil M., Konarska A., 2004. Anatomical traits of nectaries and nectar secretion by the flowers of Cotoneaster lucidus Schlecht. and C. nanshan Mottet. J. Apic. Sci. 48(1): 5562.

Weryszko Chmielewska E., Chwil M., Skrzypek H., 2003a. Charakterystyka kwiatów i nektarowanie irgi miseczkowatej Cotoneaster hjelmqvistii. Ann. Univ. Mariae Curie Skłodowska, Sect. EEE Hortic. 13: 137142. 
Weryszko Chmielewska E., Konarska A., 1995. Porównanie struktury nektarni ków wybranych gatunków z podrodziny Pomoideae (Rosaceae). Acta Agrobot. 48 (1): 3344.

Weryszko Chmielewska E., Konarska A., 1996. Anatomia nektarników kwiato wych dziewięciu gatunków z podrodziny Rosaceae. Acta Agrobot. 48, 1: 3344.

Weryszko Chmielewska E., Masi erowska M. L., Konarska A., Pezda M., 1996. Wielkość nektarników i nektarowanie niektórych gatunków Cotoneaster, Crata egus i Sorbus. Ann. Univ. Mariae Curie Skłodowska, Sect. EEE Hortic. 4: 133140.

Weryszko Chmielewska E., Masierowska M., Konarska A., 1997. Surface of the nectaries and nectar production of four Pomoideae representatives (Rosaceae). Acta Hortic. 437: 359367.

Weryszko Chmielewska E., Masierowska M. L., Konarska A., 2003b. Cha racteristics of floral nectaries and nectar in two species of Crategus (Rosaceae). Plant Syst. Evol. 238: 3341.

\section{Zróżnicowanie powierzchni nektarników kwiatowych czterech gatunków z rodzaju Crataegus $\mathbf{L}$.}

\section{Streszczenie}

Przeprowadzone badania dotyczyły budowy powierzchni nektarników kwiatowych czterech gatunków z rodzaju Crataegus: C. coccinea L., C. crus-galli L., C. curvisepala Lindm. i C. prunifolia (Poiret) Pers. Obserwacje epidermy przeprowadzono w skaningowym mikroskopie elektronowym (SEM). Nektarnik ma kształt lekko wygiętego dysku leżącego między szyjką słupka, a nasadową częścią nitek pręcikowia. Powierzchnia epidermy nektarników badanych gatunków różniła się znacznie urzeźbieniem kutykuli i liczbą aparatów szparkowych. Sekrecja nektaru w kwiatach Crataegus odbywała się przez aparaty szparkowe, które były położone poniżej poziomu pozostałych komórek skórki, w głębokich obniżeniach tkanki wydzielniczej. Największą liczbę szparek w $\mathrm{mm}^{2}$ epidermy nektarnika stwierdzono u C. crusgalli, a następnie $C$. coccinea, $C$. prunifolia $i$ C. curvisepala. Analizując kutykularną strukturę nektarników pod względem wzrastającego stopnia skomplikowania budowy (brak lub obecność prążków) badane taksony można uporządkować następująco: Crataegus curvisepala, C. coccinea, C. crus-galli i C. prunifolia. 
